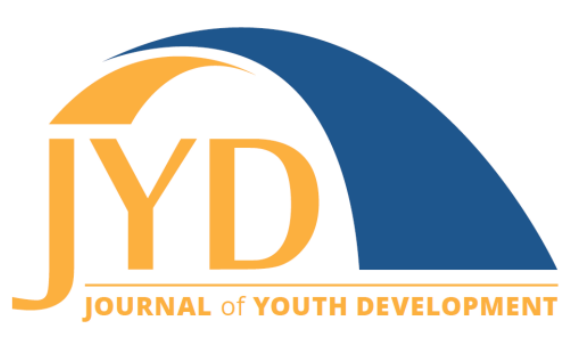

http://jyd. pitt. edu/ | Vol. 14 Issue 2 DOI 10.5195/jyd.2019.766 | ISSN 2325-4017 (online)

\title{
Big Town, Bigger Borders
}

\section{Brittany Mendez}

\begin{abstract}
This essay demonstrates how the perceptions of others can have a great impact on a young person's life. The author writes about overcoming the negative perceptions of her border community and her important journey through a STEM summer program. Her essay highlights the transformative impact summer programs can play in changing the trajectory of a young person's life by teaching valuable skills and providing opportunities to overcome personal and community obstacles.
\end{abstract}

Key words: STEM immersion program, leadership, natural environment

My freshman year of high school I began to struggle; I established myself with the unwavering confidence of an eighth-grade A Honor Roll student. I remember thinking, "I've flown through enough grade levels with A's, high school is gonna be a walk in the park." Fortunately for me, it wasn't. Shortly after the classes started, I began to lose confidence. My self-esteem plummeted faster than a blink of an eye. At the end of the first report card, I was already hanging on by a thread. As I recall it, there I was peering through that dusty window of our rickety wooden door, waiting. I waited for hours that weekend. The mail was supposed to be delivered between 8 and11am, but for some reason it was late that day. It was 11:45 a.m. and just as I was throwing in the towel, I noticed a small red blob in the corner of my left eye. My entire body grew cold. I thought to myself, "COULD IT BE?! Is it him!?" In order to not raise suspicion, I quietly announced "I'll be right back! I'm going to feed the cats!" I steadily opened that incredibly creaky door, walked through it and slowly closed it behind me. The moment I knew I wasn't in either one of my parents' sightlines, I bolted. I ran like I'd never ran before, as if getting to the mailbox before anyone else would solve all of the world's problems. I did it. I beat absolutely everyone else to the mailbox, not that anyone else was trying. In my hands, I held it. The magical envelope that would either condemn or applaud me for the following six

(cc) EY New articles in this journal are licensed under a Creative Commons Attribution 4.0 License. This journal is published by the University Library System, University of Pittsburgh and is cosponsored by the University of Pittsburgh Press. The Journal of Youth Development is the official peer-reviewed publication of the National Association of Extension 4-H Agents and the National AfterSchool Association. 
Big Town, Bigger Borders

weeks. I took a deep breath and tore the left side, top to bottom. I used my right thumb and index finger to pull the card out of the envelope. Gradually, I unflapped the trifold and my eyes grew numb. I no longer had mobility of my optic nerves-they belonged to someone else entirely. My brain could not comprehend the chaos that those seven numbers just unveiled to me.

My grades were appalling and I'm not talking about those 89 or 88 's. I know very well that struggle of holding yourself so high that the mere thought of anything lower than a 95 disgusts you. My grades were B-A-D. I think they were all low 70 s except one, it was an 85 , but that didn't count because that teacher was a saint! For the first time in my life, I was practically failing. Living by the border you become accustomed to certain stigmas, one in particular is the inability to progress because of deprivation. A considerable amount of youth wholeheartedly believe that they cannot succeed if they stay here. Based off those beliefs, your one shot ticket out of this place is education or sports. Unfortunately, I am a lot more intelligent than I am athletic, therefore, my one and only option was to get my degree and do something with my life.

After that first report card, I did my best to raise the grades and keep afloat. At the end of the day, that was all that I did-stay afloat. I finished that year with low B's and C's, but I had no hope for myself. In my eyes, I tried, failed and that was it. Summer came around and I was set on eating my feelings away like I did every other summer before-the difference this time was that I wasn't sad because other people would pick on me or make fun of my choice in music, but because I was going to be a failure for the rest of my life. Why? Because that's what happens to people who can't make it out of the valley, growing up by the border.

As a native, your culture and environment are the most influential factors that aid in the build of a Hispanic mindset. Your friends are constantly telling you that you NEED to get out, out of school, out of your house, out of the town. The options were either to graduate and leave or to stay. For the ones who left, they had the opportunity to make something of themselves, to actually follow their dreams. For the ones who stayed, they would end up working at a deadend job, most likely a fast food joint, for the rest of their lives because they never finished school. They'd have kids, pay taxes and then they'd die. At school, everyone believed that to their core. Even the teachers, you would look at them and they looked so unfulfilled. Unfortunately, some of them even shared the same mindset as their students. Agreeing that there aren't any jobs in the valley and if you wanted to make something of yourself the only option was to leave. 
So there I was, 13 years old and destined for failure. I was lying on the couch with a family-size bag of limon chips in agony, watching a few episodes of Lost, because it seemed fitting. I will admit, I am dramatic; I was probably even more dramatic at that time because I remember telling my mom "leave me here, there's nothing out there for me anymore..." She looked at me and rolled her eyes. Till this day, I don't know how she did it; but she convinced me to get off the couch and accompany her to her school. My mom is a teacher, a devoted one at that, so although school had already let out, we were going to her school to prep for the following year. We arrived at the school, went to her room and on the floor, there was this white printed flyer with green leaves on it. Either someone dropped it and it slid under the door or someone had left it for my mother-in any case, it was a flyer for a summer program open to grades 8 through 12. As I continued to read, I noticed the program was just about to start the following week. I had my reservations but I decided in favor of the program because the daunting alternative was most likely a sports camp, and there was no way you were getting me to run.

I showed up to the first day of the program with the "as long as I don't have to exercise, I'm golden" attitude. I honestly never expected to get anything out of the program. Thankfully, again, I was proven wrong. It was a summer program whose organization I'd never heard of, much less the acronym it was based on. It was a 2-week program that immersed students in science, technology, engineering, math (STEM) fields and at the end of the program, we were going to the island to do some activities and apply what we had learned. Although the summer program was short-lived, I discovered many things in those 10 days: a passion for STEM that I never knew existed; my leadership ability, that until then, I thought was nonexistent; and lastly, my innate drive for sharing my findings. Till this day, I can confidently lead a group through trails, highlighting various plants and birds, elaborating endlessly on certain features of native and nonnative species. I think back to that first day and the botany class I was introduced to. I can't even begin to explain the sheer exhilaration pumping through my body. I thoroughly enjoyed those two weeks, despite the constant walking from place to place, I'd found something that I actually enjoyed participating in.

The final day, the island day, was a bittersweet one. Our group was split into three activities: biking, fishing and kayaking. We were given the opportunity to rotate in an effort to give everyone the opportunity to try them all. I'd gone fishing and biking, all that was left was to go kayaking. Although our city has several oxbow lakes, many of them are not kayak-friendly, and most of us aren't exposed to extracurricular activities. In fact, the word kayak made us think! Some of the students had our assumptions that it was a type of boat and others had no clue. 
We went out on the water and it was pretty great. It was an experience that almost all of us never would have had if it weren't for that program. The day was coming to an end and all of the students were getting ready to board the bus. We'd brought the kayaks back to our area and starting grabbing our backpacks. Not long after, one of the mentors looked at us and asked who was going to clean up after us. We looked at him confused because we didn't understand. We had taken the kayaks back to the place we got them from, same with the life jackets. He told us to grab something and start cleaning. Perplexed, we put our bags down and went back to grab a life jacket, paddle or kayak. Slowly but surely we started an assembly line and started washing all the things we'd used. I was completely and utterly speechless. I understood what we were physically doing, but until that point, I'd never truly seen it. We weren't just cleaning supplies, we were being taught to be self-reliant, self-sufficient, supportive, helpful, independent and confident. I was literally scrubbing down a kayak when I had this epiphany and it has changed my life. I had found purpose!!! I went back to school the next year motivated, with a sense of direction. I slowly began to build my confidence and once that happened, everything else followed. My grades improved quickly and I ambitiously set out to provide those opportunities for others.

Throughout high school, I involved myself in everything I could. I volunteered with that STEM organization and even joined a few more groups along the way. In my senior year of high school, I was an active member of 16 different clubs and held officer positions in eight of them. I actively participated in my sport as well as the search for scholarships. I was awarded a fullride scholarship to one university, where I found a way to continue my passion for STEM education and outreach. I served my community while I continued my studies and built connections I wouldn't have cultivated otherwise. I took a job at the university as an understudy and had the opportunity to coordinate very distinguished events promoting STEM fields. Upon receiving my bachelor's degree, I continued my studies and earned my master's degree, all before the age of 24. To think, that 13-year-old girl, who thought she had nothing going for her, found a passion and ran with it. She followed that passion all the way to Good Samaritan Community Services, an NPO whose main focus is to serve as a catalyst for change, helping students develop their character by teaching them assets like: responsibility, support, respect, confidence and engagement.

I didn't have to leave my city to make a difference, I just had to give it a chance. How can we expect to change the world if we can't even change our backyard? Our environment and culture are a big part of who we are, yes. However, it doesn't have to be al/ that we are. Our border 
Journal of Youth Development | http://jyd.pitt.edu/ | Vol. 14 Issue 2 DOI 10.5195/jyd.2019.766

Big Town, Bigger Borders

surrounds us and at times, some see it as an undefeatable obstacle, something that suffocates, pushing us away, forcing us to abide by its rules and stigmas, but it isn't. Just because we grow up by a border, doesn't mean we have to be limited by it. 